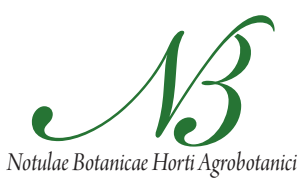

Cluj-Napoca

\title{
Innovations in the Forest Products Industry: The Malaysian Experience
}

\author{
Jegatheswaran RATNASINGAM ${ }^{1 *}$, Lim Tau WAI ${ }^{1}$, Ganesh THANASEGARAN², \\ Florin IORAS 3 , Cristina VACALIE ${ }^{4}$, Claudiu COMAN ${ }^{4}$, Lu WENMING $^{5}$ \\ ${ }^{1}$ University Putra Malaysia, Faculty of Forestry, 43400 UPM, Serdang, Selangor, Malaysia \\ jegaratnasingam@yahoo.com ("correspondingauthor);limtw@gmail.com \\ ${ }^{2}$ University Putra Malaysia, Faculty of Economics and Business Administration, 43400 \\ UPM, Serdang, Selangor, Malaysia; ganesh@putra.upm.edu.my \\ ${ }^{3}$ Buckinghamshire New University, Queen Alexandra Road, High Wycombe, HP $112 \mathrm{JZ}$ \\ Buckinghamshire,United Kingdom; florin.ioras@googlemail.com \\ ${ }^{4}$ Transilvania University of Brasov, 29 BdulEroilor,Brasov,_Romania; cris_d84@yahoo.com; claudiu.coman@unitbv.ro \\ ${ }^{5}$ Chinese Academy of Forestry, Wanshoushan Hou, Haidian District, Beijing 100091, P.R. China; luwenmingcaf@126.com
}

\begin{abstract}
The forest products industry is an important socioeconomic sector to many developing countries, both in terms of foreign exchange earnings and employment. In the case of Malaysia, the industry has been one of the fastest growing manufacturing sectors in the country, driven primarily by comparative advantages derived from factor inputs. However, with increasing competition from other cheaper producing nations particularly China and Vietnam, the Malaysian forest products industry is forced to transform and move along the value-chain through innovation and value-addition. Although the government has played a pivotal role in providing a broad policy framework to support value-adding and innovative activities, success on the ground has been limited. The creativity environment, which is plagued with by low-wage economy, coupled with limited network between research, market and industrial enterprises have stifled innovation within the industry. The lack of information and the poor quality human capital has also contributed to the limited innovation within the forest products industry in the country. Against this background, most innovation within the industry is confined to the realms of alternative raw materials, with minimal technological and design variations. Although extensive research and development activities are undertaken, the commercialization potential of the research outputs is limited due to being not market-driven. Inevitably, innovation in the forest products sector must be based on market-needs and must be driven through technological and design change in order to ensure long-term competitiveness.
\end{abstract}

Keywords: design, forest products, innovation, market, technology, value-addition

\section{Introduction}

As a developing country, Malaysia's transformation from an agricultural-based economy to a manufacturingbased economy over half a century has been astounding. In fact, the share of the manufacturing sector towards the country's gross domestic product (GDP) has been steadily increasing over the years (Fig. 1).

In this context, it is no surprise that the forest products industry in the country has also shown tremendous growth rate, both in terms of export earnings and employment provision (Ratnasingam, 2012). Blessed with a rich forest resource and an ample supply of workforce, the industry has growing rapidly with an annual growth rate of $10 \%$ since the 1980s. However, in recent years, the forest products sector has come under increasing pressure to move up the value-chain and manufacture innovative products to starve off the increasing competition from other regional low-cost producers, especially China and Vietnam (Ratnasingam, 2012).

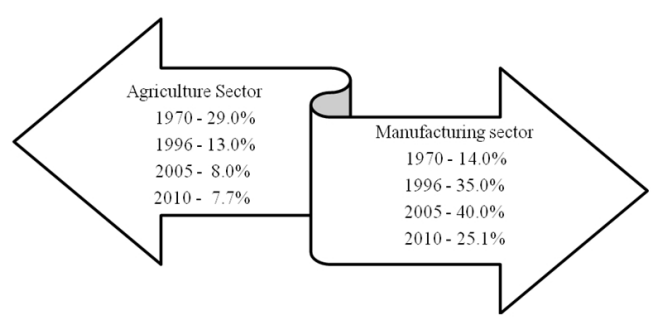

Fig. 1. Contributions of the Agricultural and Manufacturing Sectors to the Gross Domestic Product (GDP) of Malaysia

Although the blue-print for innovation activities was implemented since the mid-1990s through the 2nd Industrial Master Plan (1996-2005), the extent of innovation within the forest products industry has been limited (Ng and Thiruchelvam, 2012). Therefore, this paper aims to review the forest products sector in Malaysia and examine the extent of innovation and the challenges faced by the industry to move up the value-chain in order to remain competitive. Further, the paper provides an in-depth 
602

analysis of the drivers of innovation in the forest products sector and suggests lessons that could be learnt by other nations from the Malaysian experience.

\section{The Malaysian Forest Products Industry}

The forest industry in Malaysia has consistently contributed to the nation's economic growth, as well as its foreign exchange earnings. To date, there are almost 3900 forest products manufacturing enterprises in the country, providing employment to almost 380,000 people (DOS, 2012). The forestry and forest products sector contributed 7.8 percent to the country's GDP and 3.1 percent of the country's total merchandise export in 2011.

The forest products industry in Malaysia began in early 1900 s, focused mainly on primary processing of saw-logs and sawn timber. The government restructured the industry in the mid-1980s to ensure greater value-addition activities and also to keep pace with the dynamics of the global market. The transformation of the industry, from primary processing to the one driven by value-addition was brought about by the implementation of a series of Industrial Master Plans which spurred productivity growth within the industry (Ratnasingam, 2002a; Asid, 2010). Although, the first Industrial Master Plan (IMP-1) (19861995) did not realize its intended goals completely, the governmental slightly modified second Industrial Master Plan (IMP-2) (1996-2005) strengthened the productivity growth in the manufacturing sector (Mahadevan, 2001; Lee, 2011). In this context, the policy of restructuring the forest products industry was regarded successful as the proportion of exports of value-added products (which includes furniture, moulding, builders carpentry and joinery, wood-based panels) increased significantly compared to the exports of commodity-type low-value products such as logs, sawn-timber and plywood (Tab. 1).

Tab. 1. Constituents of Forest Products Export

\begin{tabular}{|ccc|}
\hline Year & $\begin{array}{c}\text { Primary forest } \\
\text { product }(\%)\end{array}$ & $\begin{array}{c}\text { Secondary forest } \\
\text { product }(\%)\end{array}$ \\
\hline 1990 & 68 & 32 \\
\hline 1995 & 59 & 41 \\
\hline 2000 & 50 & 50 \\
\hline 2005 & 49 & 51 \\
\hline 2010 & 48 & 52 \\
\hline
\end{tabular}

Source: Ratnasingam (2012)

In realizing the increasing regional competition, especially from low-cost producers such as China and Vietnam, the third Industrial Master Plan (IMP-3) (2006-2015) was introduced to further value-add within the industry, through innovation as well as the adoption of high technology and quality human capital (NATIP, 2009). This on-going industrial efforts have had mixed results due to the challenges that appear to stifle innovation within the industry. Fig. 2 reveals that the sub-sectors within the forest products industry have had inconsistent growth performances, although the furniture and plywood sectors appear to be on a more positive trend. This was most likely driven by the relatively greater level of innovation within these sub-sectors (Ratnasingam, 2012).

The wooden furniture industry has emerged as the largest sub-sector accounting for almost a third of the total export receipts of the country. The industry was earmarked as a target industry under the Industrial Master Plans, and was accorded special incentives to boost export growth. Inevitably, it is no surprise that the export/production ratio of the industry is in the range of $80 \%$ (Ratnasingam and Ioras, 2003).

Despite the positive sentiments reported through export statistics, it is most revealing that the net profit margin for almost all forest products exported from the country has been on the decline since the mid-1990s. This is most likely due to the stagnating productivity growth and limited value-addition within the industry (Ratnasingam and Ioras, 2005).

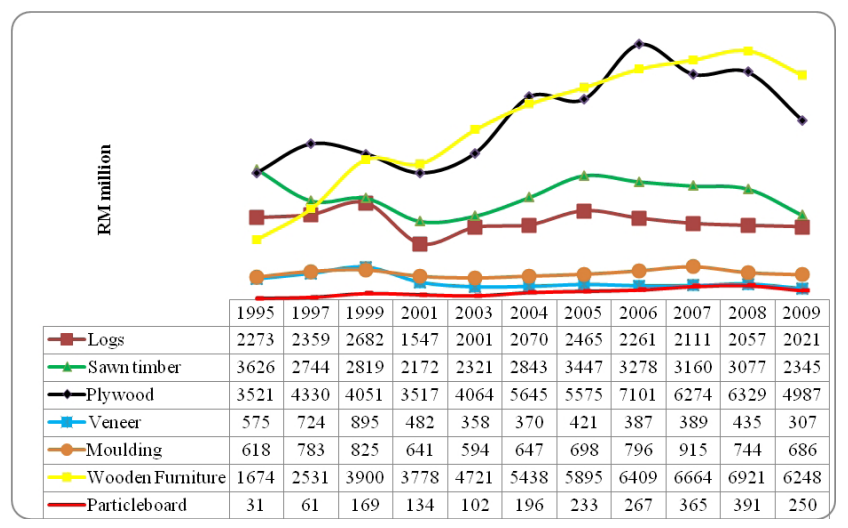

Fig. 2. The Export of Timber and Timber Products (RM million)

(Source: Malaysian Timber Council and Malaysian Timber Industry Board; Exchange Conversion: US\$ 1 = RM 3)

\section{Challenges of the Forest Products Industry in Malaysia}

\section{a. Declining Low-Cost Factor Inputs}

While Malaysia has been traditionally hailed as a lowcost production base, the comparative advantages derived from the abundant supply of wood raw materials and cheap workforce is no longer available (Ratnasingam et al., 2007). The significantly reduced supply of saw-logs from the natural forest, the overwhelming demand for plantation wood resources, particularly rubberwood (Hevea brasiliensis) and an increasing proportion of hardwoods from North America and the Oceania reflect the shortsupply of wood raw materials to cater for domestic needs. From the workforce perspective, almost $62 \%$ of the workforce employed in the forest products industry in the country is foreign-contract workers, who adversely affect skills 
retention and innovative capacities within the industry (Ratnasingam and Ioras, 2009). Against this background of declining comparative advantage, the forest products industry needs to gain competitive advantage in order to remain competitive, especially moving up further along the value-chain through innovation.

\section{b. Legality and Environment Certification}

While many forest products producing countries agree with the need to ensure the sustainable management of their forest resources, many are concerned about the complexity and cost of the certification process. Ratnasingam et al. $(2008 \mathrm{a}, \mathrm{b})$ have estimated direct cost of forest management certification of up to US\$ $1.50 / \mathrm{m}^{3}$ depending on the size of the certification unit and local conditions. Further, another US\$ $1.20 / \mathrm{m}^{3}$ may have to be added for the certification of chain-of-custody $(\mathrm{CoC})$. However, the extent of certification and CoC adoption within Malaysia is growing much slower than anticipated, as the green premium accorded to certified forest products in the global market is relatively low. The initial investment cost to obtain certification is another factor that deters forest products manufacturers from embarking on such schemes, which explains the relative low participation in the $\mathrm{CoC}$ scheme as shown in Tab. 2.

Tab. 2. Amount of Holders for Forest Management Certificate (FMC), CoC, Combined FMC and $\mathrm{CoC}$ and Controlled Wood Forest Management under PEFC and FSC Forest Certification Systems in Malaysia (2012)

\begin{tabular}{ccccc}
$\begin{array}{c}\text { Forest Certification } \\
\text { Systems }\end{array}$ & $\begin{array}{c}\text { FMC } \\
\text { Holders }\end{array}$ & $\begin{array}{c}\text { CoC } \\
\text { Holders }\end{array}$ & $\begin{array}{c}\text { Combined } \\
\text { FMC and } \\
\text { CoC }\end{array}$ & $\begin{array}{c}\text { Controlled } \\
\text { Wood Forest } \\
\text { Management }\end{array}$ \\
PEFC/MTCS & 9 & 167 & - & - \\
FSC & 0 & 177 & 7 & 2 \\
\hline
\end{tabular}

Sources: PEFC (Pan European Forest Certification), FSC (Forest

Stewardship Council) MTCS (Malaysian Timber Certification Scheme)

The efforts of the Malaysian Timber Certification Council (MTCC) and the introduction of MyTLAS (Malaysian Timber Legality Assurance System) which has had lukewarm response from the East Malaysian states of Sabah and Sarawak due to the non-binding requirements enjoyed by these states. The fact that forestry is a state matter under the Federal Constitution, limits the influence of any federal government initiatives on the states, as the states may either chose to adopt or discard these initiatives to suit their respective needs. Inevitably, certification efforts in Malaysia has been somewhat affected negatively by the reluctance of the East Malaysian states to go along with the efforts undertaken by the federal government (Ratnasingam, 2012).

\section{c. Inconsistencies in Policy Directions}

The forest products industry in Malaysia comes under the purview of several Ministries, such as the Ministry of International Trade and Industry (MITI), Ministry of Plantation and Commodities (MPIC), Ministry of Human Resources (MOHR), and the Ministry of Home Affairs (MOHA). Unfortunately, the policy directions of these ministries often contradict each other, which have affected productivity and overall industrial competitiveness. For instance, workforce being a crucial production input is often subjected to unrealistic demands, with a prime focus on the employment of local workers. The reluctance of local workers to seek employment in the forest products industry has created a gap which is often filled up by lowly-paid foreign-contract workers. On the other hand, the low-wage economy prevalent in the forest products sector in Malaysia is not lucrative to the local workers and any restriction on the employment of foreign-contract workers could halt the overall productive capacity of the industry as a whole (Reinhardt, 2000; Ratnasingam et al., 2012).

Many public research and development $(\mathrm{R} \& \mathrm{D})$ agencies have been engaged to facilitate the up-scaling of the forest products industry in the country. Unfortunately, the uncoordinated research and development efforts have often lead to efforts of "reinventing the wheel", with minimal impact towards the industry (Ahmad, 2003). The limited network between industry-academia also stifles innovation activities as the research outputs have limited commercializing potential. Despite the provision of large research grants and the availability of extensive research facilities, the lack of network and quality human capital has been cited as the main deterrent to the development of innovative new products (Dell'Era and Verganti, 2007). In essence, without a concerted and coordinated policy framework, boosting the innovative capacity of the forest products industry may remain a long-term work-in-progress.

\section{Current Status of Innovation in the Forest Products Industry}

Malaysias forest products industry is considered a matured industry with an average annual growth rate of $8 \%$ since 1986 driven particularly by its comparative advantages. However, its operational strategies, which are still in its infancy, have adversely affected its value-adding and innovation capacities (Ng and Thiruchelvam, 2012). Although statistics reveal that Malaysian forest products are on the rise, in reality the increasing exports are driven by increasing inputs without any significant gain in productivity (Ratnasingam and Ioras, 2005).

Tab. 3 reveals that despite increasing output from the forest products sector (especially the furniture sub-sector), the trend in value-addition showed a negative growth. Increasing output without significant productivity gains has created a supply-elasticity within the furniture industry, 
604

which has effectively pushed selling-prices down. Without increasing innovation, the Malaysian furniture industry will remain a mass producer of "commodity" type furniture, as previously reported by Ratnasingam (2003). Further, furniture is still not widely regarded as a fashion in Malaysia, with high levels of added-value (Ratnasingam and Ioras, 2003).

Although, Ratnasingam (2012) found that the factors such as marketing communication, technology, production cost, and demand-pattern have strong influences on the comparative advantage of Malaysian furniture, in reality it is the lack of innovation and fashion-sensitive products that appear to keep Malaysian furniture in the low-end of the global market place, competing primarily on price-points (NATIP, 2009).

Tab. 3. Productivity and value addition in Malaysian forest products industry

\begin{tabular}{cccccc}
\hline Year & $\begin{array}{c}\text { Value } \\
\text { Added } \\
(\text { RM mil) }\end{array}$ & $\begin{array}{c}\text { Value } \\
\text { Added } \\
\text { Growth } \\
(\%)\end{array}$ & $\begin{array}{c}\text { VA } \\
\text { Intensity } \\
(\%)\end{array}$ & Productivity & $\begin{array}{c}\text { Productivity } \\
\text { Growth (\%) }\end{array}$ \\
\hline 1988 & 206 & 48.2 & 56.1 & 2.28 & 4.7 \\
1993 & 596 & 41.2 & 34.9 & 1.54 & 0.1 \\
1999 & 1,582 & 23.1 & 34.4 & 1.53 & -1.3 \\
2003 & 2,223 & 10.3 & 30.0 & 1.43 & 0.1 \\
2008 & 2,833 & 7.2 & 23.3 & 1.30 & 1.2 \\
2010 & 2,961 & 6.8 & 21.8 & 1.24 & 1.1 \\
\hline
\end{tabular}

Source: Department of Statistics Malaysia

Another compelling evidence to reflect the low valueadded activity in the forest products sector in Malaysia is the value added intensity (VAI), a ratio that indicates the degree of utilization of brought-in materials (as input), and changes in the price differentials between products (output) and purchases (input) output in the industry (Tab. 4). The VAI showed a negative trend, suggesting that the forest products industry was essentially input driven, rather than value-added driven. It is undeniable that the purchase price of raw materials has been increasing steadily over the years, but the extent of value-addition was insignificant to off-set the increasing cost of factor inputs such as raw materials and labour. In recognizing this shortcoming, the government through the third Industrial Master Plan (IMP-3) (2006-2015) paid greater attention to added-value activities, especially through original product design and intensive marketing efforts (IMP-3, 2006).

Data from a survey carried out by the Innovation Agency of Malaysia in 2011 showed that the incidence innovation in forest products sector is relatively small. In fact, the majority of the innovation reported has been derived from the use of new materials rather than technology or design. Previous studies by Sales (2001) and Ratnasingam et al. (2012) have shown that innovation based on different raw materials use is unsustainable, as it is easily duplicated by competitors who may offer competitive features that easily induce the potential customers to purchase the product from them. Further, the number of patent filing for new inventions, technologies or even product design within the forest products industry has also been steadily declining from 10\% to about 4\% from the period between 1996 to 2010 (Tab. 5).

Tab. 4. Comparison of value addition between first and second IMP

\begin{tabular}{|c|c|c|c|}
\hline Period & $\begin{array}{c}\text { Average Value } \\
\text { Added } \\
\text { (RM mil) }\end{array}$ & $\begin{array}{c}\text { Average Value } \\
\text { Added Annual } \\
\text { Growth } \\
\text { Rate }(\%)\end{array}$ & $\begin{array}{l}\text { Value Added } \\
\text { Intensity (\%) }\end{array}$ \\
\hline \multicolumn{4}{|c|}{ First IMP (1986-1995) } \\
\hline MP-5 (1986-1990) & 172.0 & 30.7 & 49.8 \\
\hline MP-6 (1991-1995) & 615.4 & 34.5 & 34.9 \\
\hline \multicolumn{4}{|c|}{ Second IMP (1996-2004) } \\
\hline MP-7 (1996-2000) & $1,526.5$ & 21.6 & 34.0 \\
\hline MP-8 (2001-2005) & $2,224.8$ & 5.1 & 30.0 \\
\hline \multicolumn{4}{|c|}{ Third IMP (2006-2015) } \\
\hline MP-9 (2006-2010) & $2,743.9$ & 4.2 & 27.6 \\
\hline
\end{tabular}

Source: Department of Statistics Malaysia

Tab. 5. Incidence of Innovations in the Forest Products Sector in Malaysia

\begin{tabular}{|c|c|c|c|c|c|}
\hline \multirow[b]{2}{*}{ Period } & \multirow{2}{*}{$\begin{array}{c}\text { Incidence } \\
\text { of } \\
\text { Innovation } \\
(\%)\end{array}$} & \multirow{2}{*}{$\begin{array}{l}\text { Number } \\
\text { of } \\
\text { Successful } \\
\text { Patents } \\
\text { Filed }(\%)\end{array}$} & \multicolumn{3}{|c|}{ Sources of Innovation } \\
\hline & & & $\begin{array}{l}\mathrm{RM} \\
(\%)\end{array}$ & $\begin{array}{c}\mathrm{T} \\
(\%)\end{array}$ & $\begin{array}{c}\mathrm{D} \\
(\%)\end{array}$ \\
\hline \multicolumn{6}{|c|}{ Second IMP (1996-2004) } \\
\hline MP-7 (1996-2000) & 2.1 & 9.8 & 95 & 3 & 2 \\
\hline MP-8 (2001-2005) & 1.7 & 6.4 & 93 & 3 & 4 \\
\hline \multicolumn{6}{|c|}{ Third IMP (2006-2015) } \\
\hline MP-9 (2006-2010) & 1.8 & 3.8 & 94 & 3 & 3 \\
\hline
\end{tabular}

Note: based on a survey of 3000 forest products manufacturing enterprise; RM- raw materials, T-technology, D-design/product

The Malaysian forest products industry has grown steadily by increasing factor inputs as well as adopting the latest technology and management tools, such as computer-aided manufacturing (CAM), computer-aided design (CAD), customized machinery, and quality management systems (ISO 9001). Malaysian forest product enterprises do not lag in their acquisition of state-of-the-art technologies and the sources of technology are mostly from Germany (36\%), Italy (24\%) and Taiwan (23\%). Ratnasingam and Ioras (2005) argued that the forest products sector in Malaysia has a relatively strong appetite for imported technologies, which facilitated a rapid increase in production output. Unfortunately, less than 10\% of these state-of-theart technologies are used to value-add or produce inno- 
vative products. In this context, the technologies are used to gain on economies of scale, with the sole objective of reducing unit cost (Ratnasingam and Ioras, 2005), which in turn suggest that most forest products enterprise in the country compete on price-points rather than innovation.

The incidence of innovation in the forest products sector from the service perspective is also limited to businessto-business (B2B) e-marketplaces. A growing number of companies are also promoting their products using the internet and web-based e-catalogues (Natkuncaran and Bennett, 2009). In this context, it appears that information and communication technologies (ICT) application in the forest products sector is limited to the confines of standard ICT applications.

Mahadevan (2001) reported that the transition from the original-equipment manufacturing (OEM) concept to the original-design manufacturing (ODM) concept within the Malaysian forest products sector is relatively slow. The lack of qualified human capital together with market-exposure and technical-knowledge are the biggest stumbling blocks to the development of innovative products within the industry. Although research and development $(R \& D)$ activities have been intensified, the research outputs have had limited commercial uptake as most are deemed not production-friendly or not market-relevant (Ratnasingam, 2008).

\section{Sources of Innovation in the Forest Products Industry}

The sources of innovation in the forest products industry can be categorized as internal and external factors (Fig. 3). From a survey of 1000 manufacturing enterprises, it was found that almost $90 \%$ of the innovations reported by the respondents were from external sources, particularly the technology-providers (machinery suppliers) and the customers or buyers ( $\mathrm{Ng}$ and Thiruchelvam, 2011). In fact, the internal sources of innovation, which includes the human-capital and in-house research and development $(\mathrm{R} \& \mathrm{D})$ activities are often focused on solving-problems and reducing cost, rather than developing new, innovative products.

In previous studies by Lean (2008) and Ratnasingam (2012), it was reported that the sources of innovation within the forest products enterprises are often related to product aesthetics and raw materials use, while the technology/machinery suppliers and customers are often providing innovative ideas based on market and competitive needs. In this context, it may be construed that the research and development $(\mathrm{R} \& \mathrm{D})$ activities undertaken by the public and private organizations related to the forest products industry has not borne the necessary fruits to foster creativity and innovativeness. The argument that most of the research are based on established-themes and lack real-fundamental discoveries appears to be valid. According to the report by Ahmad (2003), the research intensity for the forest products sector has increased significantly from 1990s, but in terms of commercialization success, the record appears dismal. The foreign investors in the forest products sector in Malaysia have also had minimal influence on the level of innovation within the sector, as most of these enterprises are geared towards maximizing production economics on the grounds of favourable cost-factors and fiscal incentives accorded to the them (Ratnasingam and Ioras, 2009; Ali et al., 2010).

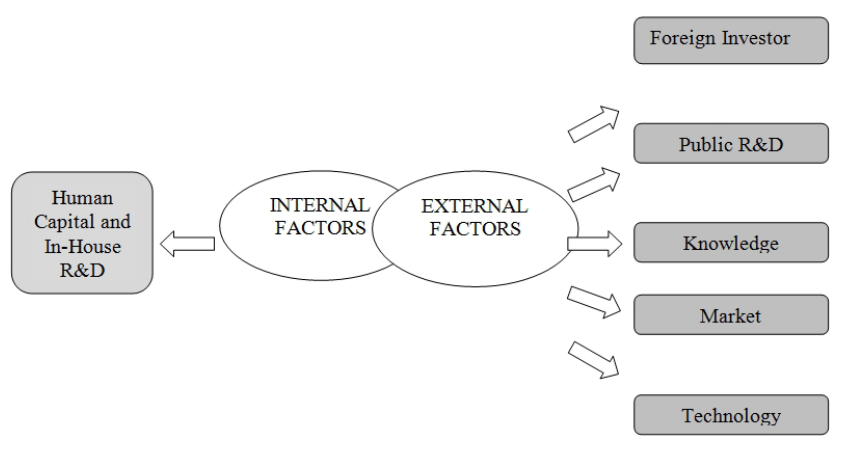

Fig. 3. External and Internal Sources of Innovation

Constraints to Innovation in the Forest Products Sector

Studies have shown a number of factors hindered the innovative efforts of the forest products enterprises in $\mathrm{Ma}$ laysia (Reinhardt, 2000; Ratnasingam, 2012). These factors include the lack of knowledge to innovate, lack of promotion and market-knowledge, and the high cost associated with research and development $(\mathrm{R} \& \mathrm{D})$ activities, especially among small and medium enterprises (SMEs). The perceived economic risk and the lack of market-demand for innovative products were also the other constraints that hampered innovation activities in the forest products industry in Malaysia. In essence, cost and market-related factors have stifled innovative efforts in the industry, so much so that the production capacity is used to compete on lower unit cost through economies of scale rather than product creativity and diversity, as reported previously (Ratnasingam and Ioras, 2005). The poor network between industry-research organizations-academia has been identified as a major stumbling block to innovation in the forest products sector as it affects the on-going research trends, human capital quality and the commercialization potential of the outputs (Ratnasingam, 2012).

\section{Lessons Learnt and Successful Models}

Despite the encouraging growth and export performance of the forest products sector in Malaysia, it is apparent that the industry lags behind in-terms of innovation and creativity when compared to their counterparts in Germany and Italy as illustrated in Tab. 6 (Bhattacharya, 2002; Ratnasingam, 2012). The salient lesson that could be learnt from the Malaysian industrial transformation process is the fact that government policy direction must be linked closely with capacity on the ground, failing which the industry could be trapped in its "development phase". The transition of the forest products sector, espe 
Tab. 6. Comparative Innovation Models

\begin{tabular}{|c|c|c|c|}
\hline & Malaysia & Germany & China \\
\hline $\begin{array}{c}\text { Value-Added per } \\
\text { Employee/year (US\$) }\end{array}$ & 28,000 & 137,000 & 22,000 \\
\hline $\begin{array}{l}\text { Average Annual Industrial } \\
\text { Growth Rate (\%) }\end{array}$ & 8 & 2.5 & 18 \\
\hline Rate of Technical Change (\%) & 2.5 & 25 & 5.5 \\
\hline Sources of Innovation & Materials & Technology and Design & Market \\
\hline $\begin{array}{c}\text { Average R \& D Expenditure } \\
\text { per Mill (US\$) }\end{array}$ & 15,000 & 150,000 & 25,000 \\
\hline Education Model & Traditional & Apprenticeship and Traditional & Traditional \\
\hline Innovation Network & Industry & Industry-Academia & Industry \\
\hline
\end{tabular}

Source: Ratnasingam (2012)

cially the furniture industry which has been trapped in the OEM phase for the last two decades, without making significant progress towards the ODM phase is ample testimony to this fact. The lack of market-driven research, skills enhancement among workers and long-term program to boost creativity and innovation by "making things with the hands" have all contributed to this persistent OEM trap faced by the forest products industry at large (Lee and Lee, 2007). Nevertheless, the vigor with which the government embarks on new policy directions, especially the third Industrial Master Plan and the National Timber Industry Plan (NATIP) could indeed be initiatives in the right direction.

\section{Conclusions}

The need for innovation and creativity within the forest products is a necessity for sustainable forest products industry throughout the world. It is apparent that in many traditionally forest resource rich nations, innovation has often been lagging behind as the industry was poised to boost industrial output based on economies of scale rather than innovation and value-addition. The Malaysian experience in transforming its forest products industry from primary-processing oriented to one driven by value-addition and innovation through strong policy framework is laudable. However, for the forest products industry to progressively move along the value-chain through innovation requires a combination of factors that must come into play to spur creativity, which in the Malaysian case has been plagued with challenges. Nevertheless, it must be emphasized that the innovative environment could be created by emulating successful models practised elsewhere in the world.

\section{References}

Ali H, Ahmad S and Muhamad R (2010). Determinants of Foreign Direct Investment Locations in Malaysia. International Review of Business Research Papers 6(4):101-117.

Ahmad AH (2003). The Participation of the Wood Based
Sector in the Malaysian Research and Development Grant Scheme. UPM Press, Serdang.

Asid R (2010). Technical Efficiency Analyses of Manufacturing Sector in Malaysia: Evidence from the First Industrial Master Plan. Asian Social Science 6(2):99-107.

Bhattacharya M (2002). Industrial Concentration and Competition in Malaysian Manufacturing. Applied Economics 34(17):2127-2134.

DOS (2012). Statistics on the Forest Products Industry. Department of Statistics Database, Putrajaya.

Dell'Era C, Verganti R (2007) Strategies of innovation and imitation of product languages. Journal of Product Innovation Management 24(6):580-599.

IMP-3 (2006). Third Industrial Master Plan (IMP) 2006-2020. Malaysia, Ministry of International Trade and Industry, Kuala Lumpur.

Lean HH (2008). The Impact of Foreign Direct Investment on the Growth of the Manufacturing Sector in Malaysia. International Applied Economics and Management Letters $1(1): 41-45$.

Lee C (2011). Trade, Productivity, and Innovation: Firm-level Evidence from Malaysian Manufacturing. Journal of Asian Economics 22:284-294.

Lee C, Lee CG (2007). SME Innovation in the Malaysian Manufacturing Sector. Economics Bulletin 12(30):1-12.

Mahadevan R (2001). Assessing the Output and Productivity Growth of Malaysia's Manufacturing Sector. Journal of Asian Economics 12:587-597.

NATIP (2009). NATIP National Timber Industry Policy 20092020. National Timber Policy. Ministry of Plantation Industries and Commodities, Malaysia.

Natkuncaran J, Bennett G (2009). Creativity and Innovation Lessons for Beginners. Pustaka Alam Press, Kuala Lumpur.

Ng BK, Thiruchelvam K (2011). Sectoral Innovation Systems in Low-Tech Manufacturing: Types, Sources, Drivers and Barriers of Innovation in Malaysia's Wooden Furniture Industry. International Journal of Institutions and Economies 3(3):549-574. 
Ng BK, Thiruchelvam K (2012). The Dynamics of Innovation in Malaysia's Wooden Furniture Industry: Innovation Actors and Linkages. Forest Policy and Economics 14:107-118.

Ratnasingam J (2002). The Malaysian Furniture Industry - A Pocket Guide. Irama Prasada Publications, Kuala Lumpur.

Ratnasingam J (2003). A Matter of Design in the South East Asian Wooden Furniture Industry. Holz als Roh-und Werkstoff 61:151-154.

Ratnasingam J, Ioras F (2003). The Sustainability of the Asian Wooden Furniture Industry. Holz als Roh-und Werkstoff 61:233-237.

Ratnasingam J, Ioras F (2005). The Asian Furniture Industry: Reality behind the statistics. Holz als Roh-und Werkstoff 63(1):64-67.

Ratnasingam J, Ioras F, Macpherson TH (2007). Influence of wood species on the value of wooden furniture: the case of Rubberwood. Holz als Roh-und Werkstoff 65(6):487-489.

Ratnasingam J, Macpherson TH, Ioras F, Abrudan IV (2008a). Chain of Custody Certification among Malaysian furniture manufacturers: Status and Challenges. International Forestry Review 10(1):23-28.

Ratnasingam J, Macpherson TH, Ioras F (2008b). An assessment of Malaysian wooden furniture manufacturers' readiness to embrace chain of custody (COC) certification. Holz als Roh-und Werkstoff 66(5):339-343.
Ratnasingam J (2008). Internationalization of Furniture Design in Malaysia. Proc. IFCX International Furniture Conference \& Exhibition, 13-46.

Ratnasingam J, Ioras F (2009). Foreign direct investment (FDI), added value and environmental-friendly practices in furniture manufacturing: the case of Malaysia and Vietnam. International Forestry Review 11(4):464-474.

Ratnasingam J, Ioras F, Abrudan IV (2012). An Evaluation of Occupational Accidents in the Wooden Furniture Industry - A Regional Study in South East Asia. Safety Science 50:1190-1195.

Ratnasingam J (2012). Innovation in the Malaysian Wood Industry - Current Status, Challenges and Future Potential. IFRG Report No. 23, Singapore, 61p.

Reinhardt N (2000). Back to Basics in Malaysia and Thailand: The Role of Resource-Based Exports in Their Export-Led Growth. World Development 28(1):57-77.

Sales C (2001). Technological innovation in the wood sector. Unasylva - An international Journal of Forestry and Forest Industries 52(3):46-61. 